\title{
近年における疲労研究の趨勢 Recent Trends of Fatigue Research
}

\section{まえがき}

金属疲労は，力学的因子と金属学的因子が複雑に関係する現象である。この現象に係る学術知と，長年に渡り「物づ くり」現場で培われてきた経験知は, 機械製品の健全性を適切に保証する上で極めて重要である. 近年, 社会一般や各 種産業分野におけるニーズが製品の軽量化, 高機能化および高付加価值化一向けて急速に変遷し, また現場における経 験知の継続的伝承が困難となりつつある中で，金属疲労に直接関係する研究者や技術者は，減少する傾向にある．この ような専門知識を有する人材の減少は, 必要とされる製品性能を十分に発揮させ, かつ安全性への配慮を㤐らないとい う, 日本の産業分野に優位性をもたらす設計・製造理念が，将来的に損なわれる可能性があることを示唆する.

一方, 金属疲労に係る研究を含め, 近年における学術研究は焦点を絞って実施される傾向がある. そのため, 少数の 文献を参照しても, 注目する分野の全体像や工学的意義などを把握することは困難となっている. このことから, 各種 分野における疲労研究を俯瞰し, 近年における研究の趨勢を把握することは, 実務に携わる技術者のみならず, 関係分 野を学術的に発展させようとする研究者にとっても有益であると考えられる. 以上の観点から, 本講座では「近年にお ける疲労研究の趨勢」と題して，金属疲労に係る5つのトピックスについて解説する.

疲労現象やその影響因子に係る研究については, 現在でも超高サイクル疲労や, 高輝度放射光などの応用によるき裂 発生部の形状および金属学的関連性などに関し, 発展的基礎研究が進められている。その一方で, マグネシウムなどの 軽金属, 新たに開発された表面処理を施した材料, あるいは近年注目されている接合技術および積層造形技術により作

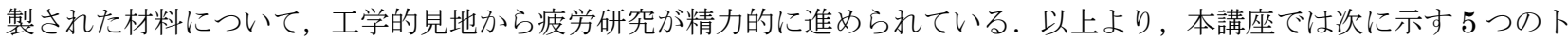
ピックスについて，各分野の専門家が解説する．読者の一助になれば幸いである.

1. 摩擦摚拌接合材および積層造形材の基本性状と疲労強度 (2017 年 5 月号, 本号)

2. 超高サイクル疲労研究の動向と展望 (2017 年 6 月号)

3. 微粒子ピーニングを応用した表面改質と疲労特性に及ぼす効果（2017 年 7 月号）

4. 高輝度放射光を利用した疲労損傷の計測 (2017 年 8 月号)

5. 非鉄金属の疲労挙動－ $\mathrm{Al}$ 合金および $\mathrm{Mg}$ 合金を中心としてー（2017 年 9 月号）

京都工芸繊維大学 機械工学系 森田 辰郎

\section{1. 摩擦摚拌接合材および積層造形材の基本性状と疲労強度†}

森田 辰郎*

\section{I: Basic Properties and Fatigue Strength of Friction-Stir-Welded Materials and \\ Additive-Manufactured Materials}

by

\section{Tatsuro MORITA*}

Key words: Fatigue, Microstructure, Stress concentration, Friction stir welding, Additive manufacturing

\section{1 緒言}

エネルギー価格の上昇や社会的要求の高度化を背景と して，近年，各種の機械製品には軽量化に基づく効率向 上が強く求められている。 これを具体的に達成するため には，単に従来材料を比強度が高いアルミやチタン等の
軽金属へ代替するだけでなく，費用対効果を考慮しつつ， 新たな接合技術や加工技術を応用して, 適切な製品形状 を実現することが必要である.

優れた接合技術の一つである摩擦擋拌接合 (以後, FSW) は，すでにアルミ製鉄道車両などの大型構造物に実用化

$\dagger$ 原稿受理 平成 28 年 10 月 5 日 Received Oct. 5, 2016 @2017 The Society of Materials Science, Japan

* 正 会員 京都工芸瀻維大学 機械工学系 $7606-8585$ 京都市左京区松崎御所海道町

Faculty of Mechanical Engineering, Kyoto Institute of Technology, Sakyo-ku, Kyoto 606-8585 
されている ${ }^{1), 2)}$. 近年には, FSW をチタン等の難加工材 3), 4)や異種材料の接合 5), 6) 人応用するため, さらに研究が 進められている。また，最近注目されている積層造形技 術は，複雑な内部構造や外形状を実現可能であるのみな らず，金型が不要であることから，少量製品の製作も容 易である，そのため，積層造形技術は次世代の加工法と して，医療用インプラントや航空宇宙関連部品への応用 が積極的に検討されている7),8).

FSW や積層造形技術については，現在までに多数の研 究が報告されている。これらの研究により，FSWを用い て接合した材料では，接合部の各種性状が明確に把握さ れている ${ }^{9)}$.また, 積層造形技術により作製した材料では, 微視組織や応力集中部となる造形欠陥などについて，有 用な知見が得られている ${ }^{10), 11)}$ 。しかしながら，組織形態 や応力集中部の存在は, 製品の健全性を保証する上で重 要な疲労強度に著しい影響を及ぼすことから，上述の新 たな技術を適用した材料においても，実用上，それらの 影響に係る包括的な知識が必要となる.

一方，近年の研究は焦点を絞って実施されることが多 いため, 少数の研究報告を参照しても, 対象分野の全体 像や工学的意義を把握することは困難である。それゆえ， 対象分野の現状を再度，俯瞰的に把握することは，関係 技術を発展させようとする工学研究者や，実務に携わる 技術者にとって有益である.

以上の観点から，本稿では FSW 接合材および積層造形 材に関し，微視組織等の基本的な性状と関連づけて疲労 特性を包括的に説明しようと試みる。具体的には，技術 内容や背景を含めながら，FSW により接合したアルミ合 金，その異種接合材および積層造形技術により作製した チタン合金に注目して説明する。

\section{FSW材の性状と疲労特性}

2.1 同種材料のFSW FSWは，1991年にTWI（the Welding Institute）によって開発された固相接合法である 12). 図1の説明図に示すように，この接合法は先端にピ ン形状の突起（以後，プローブ）を有する回転ツールを 被接合材の板材間に通過させ，これにより目的とする接 合を達成する方法である，接合後，回転ツール挿入側の 表面には回転ツール肩部の通過痕が，またその背面には プローブの通過痕が認められる，以後，図1に示すよう に，接合方向（回転ツールの移動方向）をWD，板材の 厚さ方向をND，その横方向をTDと表記する.

図2に，FSWにより接合したアルミ合金A6N01-T5押出 し成形板材（以後，FSW材）について，接合部の断面様 相と硬さ分布をまとめて示す。図3には，図2に示す3領 域で実施されたEBSD分析の結果（IPFマップおよび極点 図）を示す。

図2に示すように，回転ツールの通過により材料が擋 拌された領域（以後, 擋找部）は, エッチングによるコ ントラストを通じて光学的に判別される．顕著な塑性変 形のため，撹找部では動的再結晶を通じて組織が微細化 されるとともに ${ }^{13), 14)}$ ，回転ツール（プローブ）周囲の各 部に明瞭な方位を有する特異な形態の集合組織が形成 される(図3)。しかしながら，撹拌部の硬さは，組織が 微細化する一方でFSWにともなう熱影響により時効処 理の効果が損なわれるため, 元材の值よりも低下寸る.

擋拌部の周囲には，一般に HAZ（heat affected zone）と 呼ばれる領域が形成される。この領域では，擋找部のよ うな組織の微細化が生じない上に，FSW にともなう熱影 響により時効処理の効果が損なわれるため，硬さは著し く低下寸る，その結果，引張試験時には HAZ が優先的な
A-sideのばり

(a)
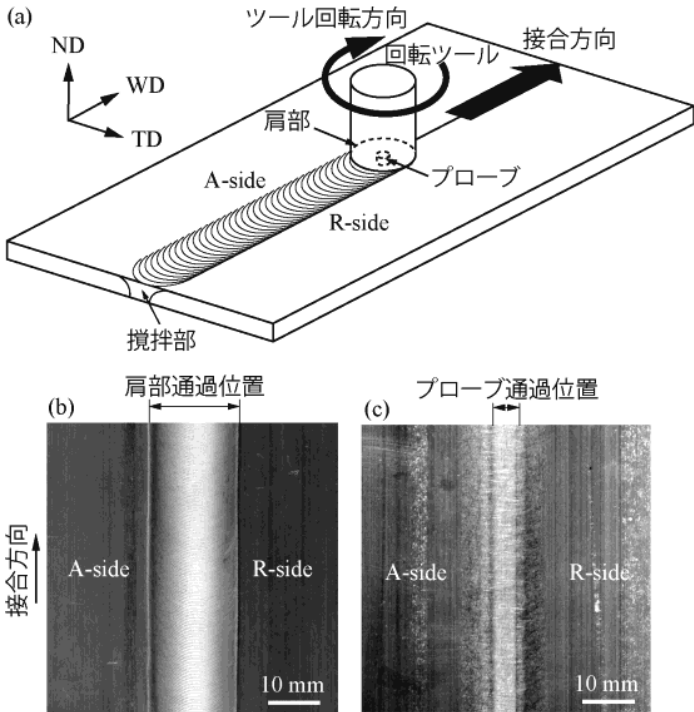

図1 FSWの説明図：(a) 模式図，(b) ツール挿入側表面 の様相, (c) 背面の様相 ${ }^{15}$

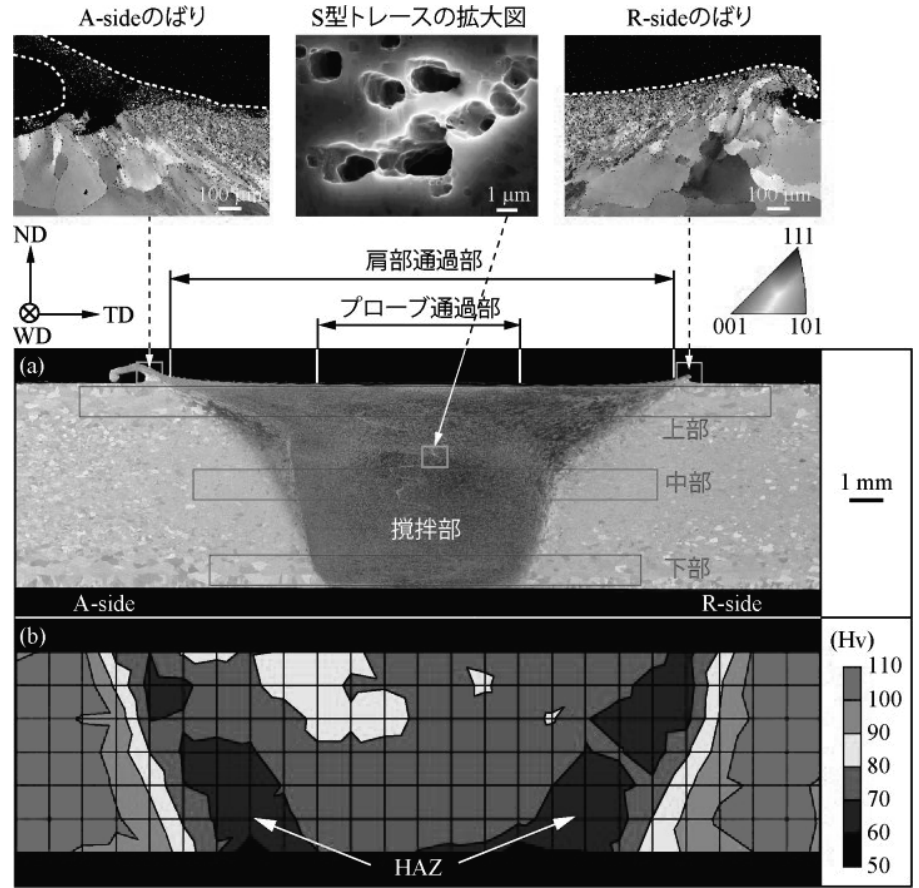

図2 FSW材の断面様相と硬さ分布：(a) 接合部の断面様相, (b) 硬さ分布 ${ }^{15}$ 
肩部通過部
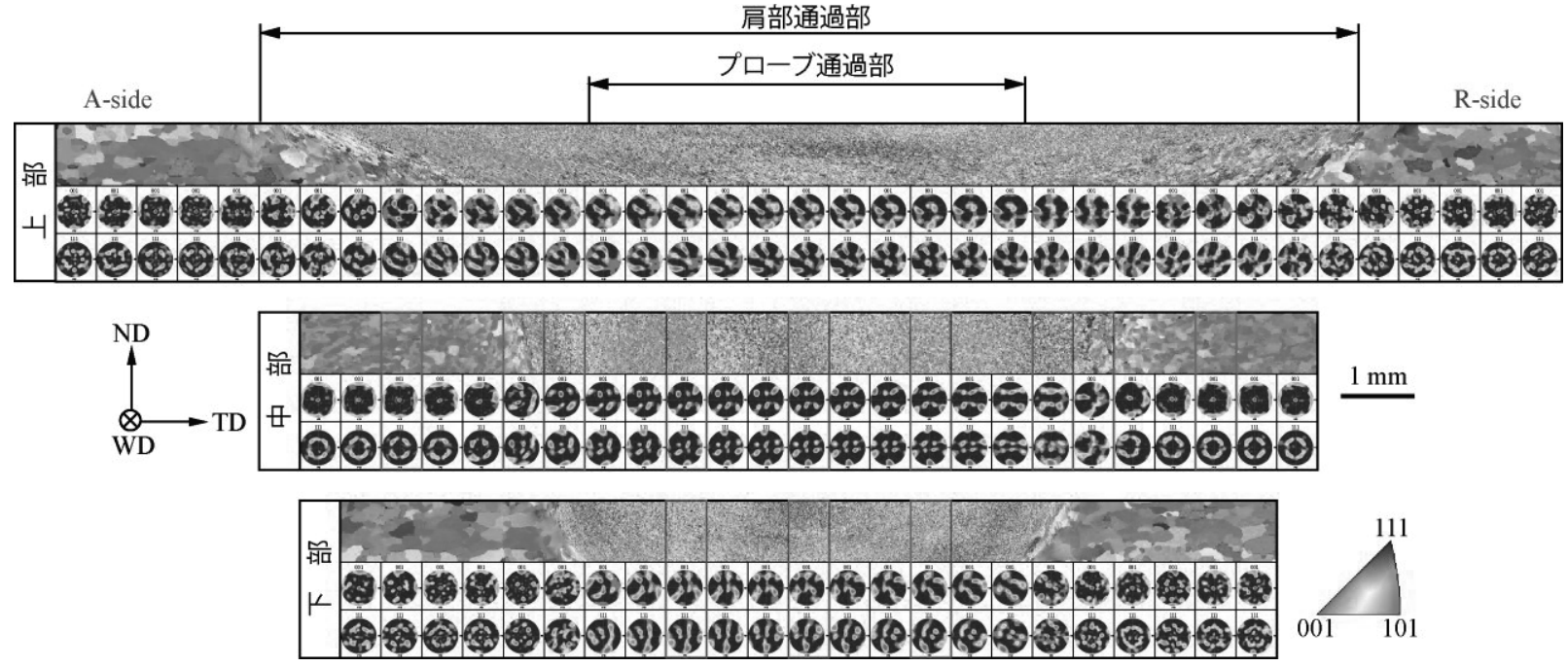

図3 FSW材各部のEBSD分析結果 ${ }^{15}$

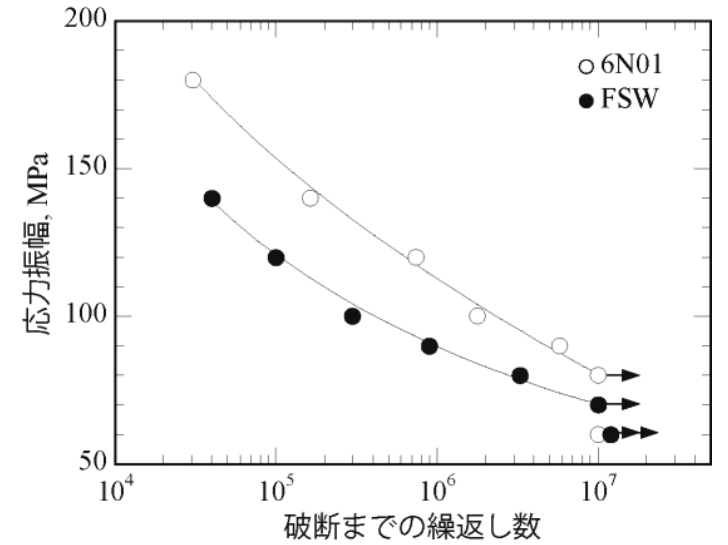

図 4 6N01 合金（元材）と FSW 材の S-N 曲線（平面曲げ疲労試 験, 応力比 $R=-1$ ） ${ }^{15)}$

破壊領域となる，それでも，FSW 材の引張強度は元材の 值に対して $80 \%$ 程度と高い水準に維持される ${ }^{15)}$.

図4に，6N01合金元材とFSW材のS-N曲線を示す。な お，疲労試験に用いたFSW材の表面は，接合ままの状態 である。図5には，疲労破壊したFSW材の巨視的様相を 示寸。図4から理解されるように，FSW材の疲労強度は 元材の值より低いものの, その值は元材の $88 \%$ と高い水 準にある。

FSW材には，不可避的に回転ツール肩部の通過位置に 「ばり」が形成される（図2）。この部位は，FSWにとも なって形成される応力集中部である，その上，同部位は HAZの延長線上に位置しているため，他の領域よりも硬 さが低い，それゆえ，FSW材における疲労き裂は，図5 に示すように，ばりの底部から発生することが多い，特 にA-side（advancing side）に形成されるばりは，R-side (retreating side) よりも大きいことから, 疲労き裂の主 たる発生起点はA-sideとなる，以上のことから，FSW材 の疲労強度は, 回転ツール肩部の通過位置に形成される

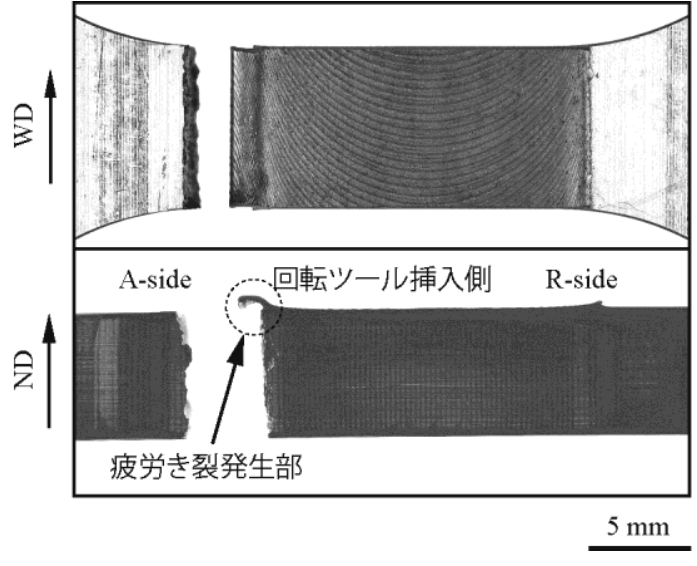

図 5 疲労破壊した FSW 材の巨視的様相 ${ }^{15)}$

ばり底部（主としてA-side）でのき裂発生限界に支配さ れると考えられる.

実用上，FSW により形成されるばりは除去されないこ とが多い、ばりを積極的に残すことにより，疲労き裂の 発生位置を限定し，保守点検を容易にするという工学的 観点もありうるが，FSW 材の疲労強度を詳細に検討する 場合や，その改善を考える際には，ばりの形成およびそ の底部における硬さを考慮することが重要となる.

2.2 異種材料の FSW 各種の産業分野では, 以下で説 明する事例のように，しばしば異種材料の接合が必要と なる。このような場合にも，FSW は他の接合法にはない 優位性を有する。

自動車産業では，高級車において鉄鋼材料からアルミ 合金への代替が進められている一方で，一般大衆車にお ける同合金の使用は限定的である。その理由は，アルミ 合金への代替による軽量化が燃費や運動性能の向上をも たらす反面，価格が著しく上昇するためである，過渡的 には，従来材料である鉄鋼材料とアルミ合金の併用が現 
実的である。しかしながら，この場合には電食問題の解 決以外に，異種材料の適切な接合技術が必要となる.

鉄鋼材料とアルミ合金を溶融溶接した場合，脆弱な高 次の金属間化合物が接合界面に形成されるため，接合強 度は著しく低くなる ${ }^{16)}$ 。これに対し，FSW は固相接合で あることから，溶融溶接のような顕著な強度低下は生じ ない，それゆえ，FSW は今後，鉄鋼材料とアルミ合金の 接合技術として，積極的に活用されると考えられる.

上記のことから, 以下では異種接合材の代表例として, アルミ合金 A6061-T6 板材（以後，6061 材）と冷間圧延 鋼板 SPCC-D（SPCC 材）を FSW により接合した材料 (6061/SPCC 材) について説明する ${ }^{17)}$, 18)。なお，一般に アルミ合金同士の接合では突合せ面中央にプローブを挿 入するが，上記の異種材料間の接合では，突合せ面とプ ローブ側面が接する状態でアルミ合金側にプローブを挿 入した. また，接合時には A-side が SPCC 材，R-side が 6061 材となるように各材料を設置した.

図 6 に，6061/SPCC 材における接合部の断面様相を， 各部で実施した EBSD 分析の結果とともにまとめて示す. 図 7 には，接合部の硬さ分布と元素分布を示す。図 8 に は, 6061/SPCC 材の接合界面における元素 (Al および Fe) の拡散状態を示す.

図 6 から理解されるように，回転ツールを傾斜(後退角 $5^{\circ}$ ) させたため, 6061/SPCC 材の接合部下方では SPCC 材が 6061 材側へ回り込む形態となった。また，接合部の 6061 材側には，局所的に空孔や，回転ツールにより削り 取られた SPCC 材小片の混入が認められた（図 7)。しか しながら，適切な接合条件を選定すれば，FSW は大きな 接合欠陥を形成することなく，異種材料間でも概小良好 な接合状態を実現することが可能であった。

6061/SPCC 材の EBSD 分析結果（図 6）から理解され るように，撹拌部の 6061 材側では，組織が顕著に微細化 した. しかしながら, 先述の同種 FSW材の場合と同様に,
接合時の熱影響のため，これらの領域の硬さは 6061 元材 $\left(110 \mathrm{H}_{\mathrm{V}}\right)$ よりも低下した（図 7).

一方, SPCC 材側の接合界面近傍でも, 組織の微細化が 認められた。この領域では, 回転ツールの通過により加 工硬化およびひずみ硬化が生じた，以上の結果，SPCC 材 側の接合界面近傍の硬さは，元材の硬さ $\left(140 \mathrm{H}_{\mathrm{V}}\right)$ より も高くなった。

X 線回折の結果は，溶融溶接の場合と異なり，6061/ SPCC 材の接合界面に強度低下をもたらす金属間化合物 が形成されないことを示した. また, 図 8 から理解され るように，接合界面では $\mathrm{Al}$ および Fe の相互拡散が認め られた。このような相互拡散は，界面強度の向上に寄与 すると考えられた ${ }^{17)}$.

図 9 に, 6061 材と 6061/SPCC 材の S-N 曲線を示す. 図 10 には, 6061/SPCC 材の疲労破面を示す. 引張試験時に, 6061/SPCC 材は 6061 材側から破断し, その引張強度は 6061 材の $83 \%$ \%達した. また, 図 9 から理解されるよう に, 6061/SPCC 材の疲労強度は 6061 材よりも低かったが, それでも 6061 材の 77\%と高い水準となった.

6061/SPCC 材の疲労き裂は，破断したすべての試験片 で，回転ツール挿入側と反対側の接合界面から発生した 後，材料内部へ進展した（図 10）。このような疲労き裂の 発生部は，接合が不十分であった領域であると考えられ る. 以上のことから，6061/SPCC 材の疲労強度は，接合 不十分な領域からのき裂発生限界に支配されると考えら れる。したがって，異種接合材の疲労強度を改善するた めには，そのような領域の形成を可能な限り抑制する必 要があると言える.

\section{3 積層造形材の性状と疲労特性}

近年注目されている積層造形法は, CAD データから直 接, 任意の 3 次元形状を有する金属製品を成形可能な優 れた加工法である．この方法では， $\mathrm{CAD}$ データに基づい て，高エネルギービームを粉体床の上で走査し，選択的

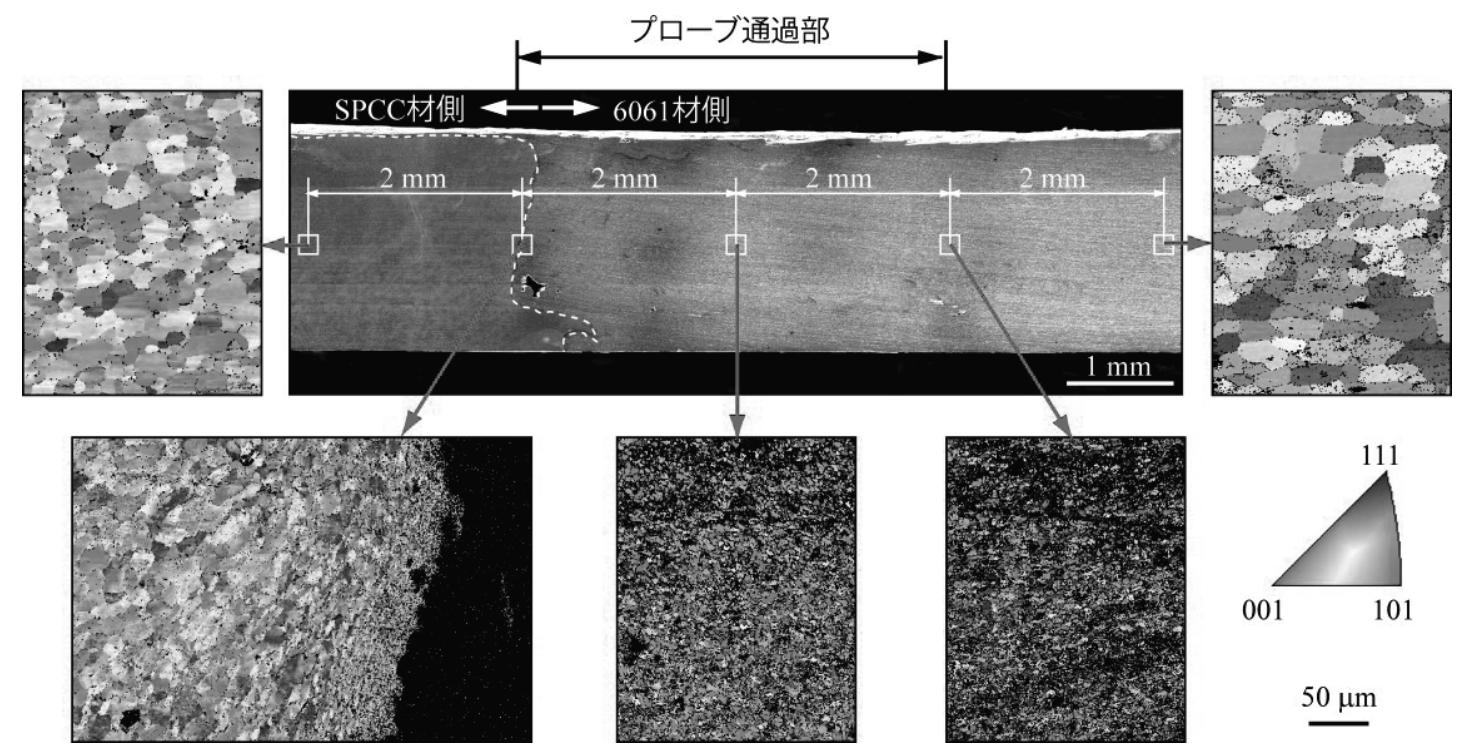

図 6 6061/SPCC 材における接合部の断面様相と各部の EBSD 分析結果 ${ }^{17}$ 


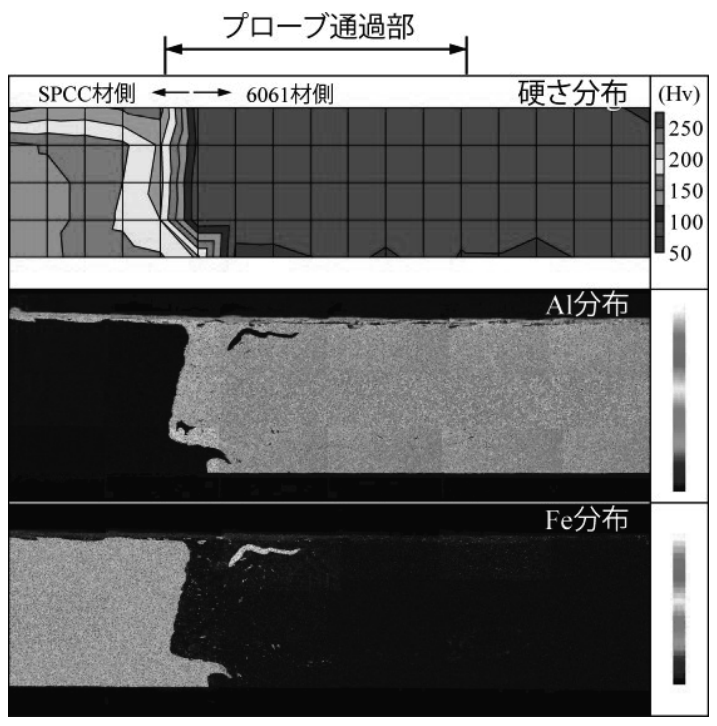

図 7 6061/SPCC 材の接合部における硬さ分布と元素分布 ${ }^{17)}$

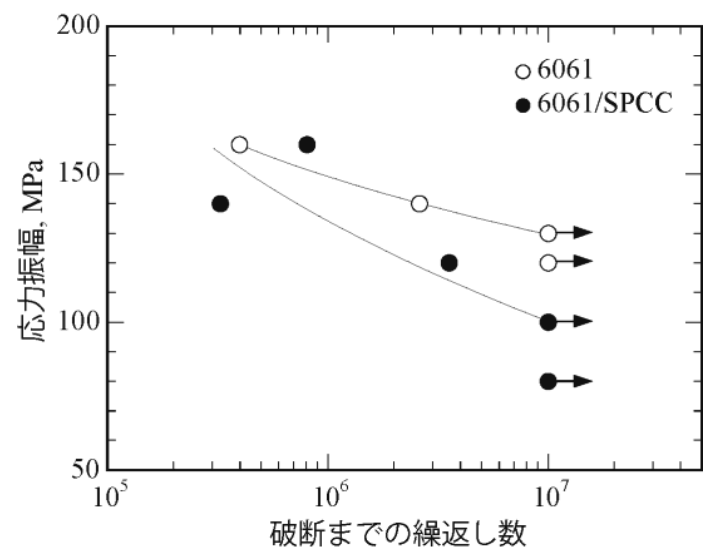

図 96061 元材と 6061/SPCC 材の S-N 曲線（平面曲げ疲労試験,

応力比 $R=-1)^{18)}$

に溶融した層を逐次的に積層させることにより製品が完 成する（図 11）。高エネルギービームとしては，一般にレ 一ザあるいは電子線が用いられる。積層造形法は, 使用 されるビームに依存して SLM（selective laser melting）法 およびEBM（electron beam melting）法に分類される.

積層造形法は，複雑形状を有する少量製品を難加工材 料から作製する場合に顕著な優位性を示す，例えば，航 空宇宙分野ではエンジンのケーシングなど，また医療分 野では個々人に最適化された形状を有するテーラード・ インプラントーの応用が期待されている．ただし，同じ 化学成分を有する金属材料であっても，展伸材と積層造 形材とでは組織や性質が異なる。そのため，積層造形法 を工学的に活用する際には，十分に展伸材との相違を認 識する必要がある.

以下では，代表的な $\alpha+\beta$ 型チタン合金である Ti-6Al$4 \mathrm{~V}$ 合金を例に挙げて，展伸材（図では記号 $\mathrm{W}$ で表記）と SLM 法により作製した積層造形材（SLM 材）の相違につ いて説明する ${ }^{19)}$. 図 12 に, SLM 材の造形欠陥の例を示 す. 図 13 には, 展伸材と SLM 材の微視組織をまとめて
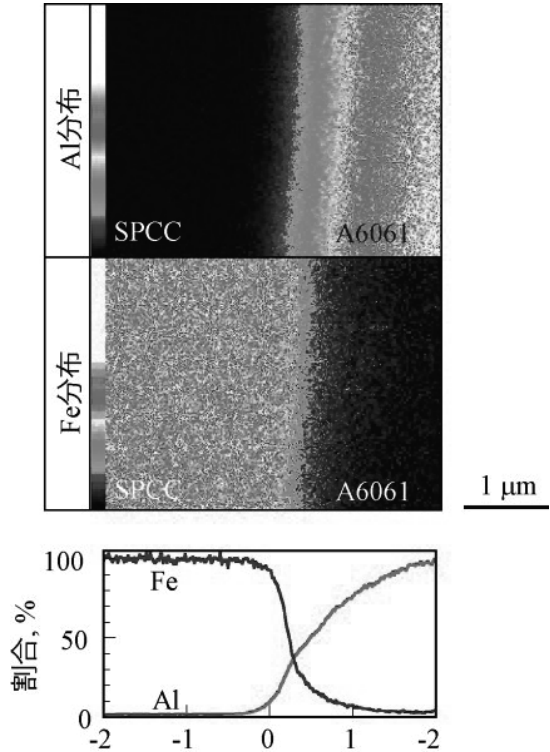

界面からの距離, $\mu \mathrm{m}$

図 8 6061/SPCC 材の接合界面における元素分布 ${ }^{17)}$

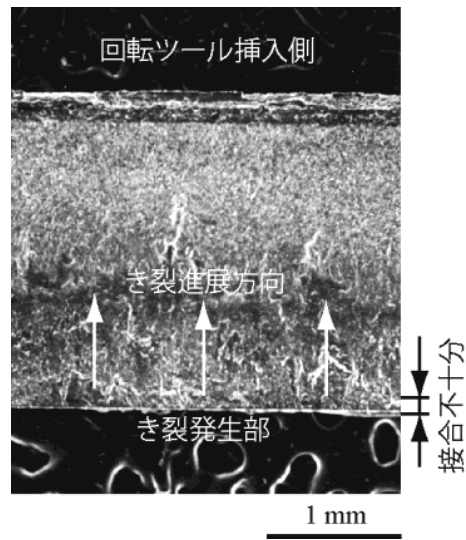

図 $106061 / \mathrm{SPCC}$ 材の疲労破面 ${ }^{18)}$

示す.

近年, 技術改良が進められた結果, 積層造形材の密度 は顕著に高められている. 実際, 本稿で説明する SLM 材 では，展伸材に対する相対密度は $99.89 \%$ \%回っていた。 それでも, 図 12 に示寸ように, 微細な造形欠陥（最大 40 $\mu \mathrm{m}$ 程度）が形成される。このような久陥の形成は, 雾囲 気ガスの残留, 粉末粒子の不十分な溶融, あるいは造形 中に舞い上がる粉塵の再混入などに起因寸ると考えられ， それらを完全に防止することは困難である。

図 13 に示すように, 展伸材の微視組織は等軸状の $\alpha$ 相 (hcp）とその周囲に位置する $\beta$ 相 (bcc) から構成される. 一方, SLM 材の微視組織は展伸材とまったく異なり, 積 層方向へ伸びる柱状組織内に針状組織が認められる.

このような柱状組織は, 以下の過程を通じて形成され る.まず，レーザが照射されて粉末粒子が溶融すると， 熱影響により溶融層下の領域が再び $\beta$ 相となる. 溶融層 は, その $\beta$ 相の結晶方位と関係して凝固し， $\beta$ 相となる。 これが繰り返されるため, SLM 材の組織は積層方向へ伸 びる柱状となり, 同組織内の結晶方位には密接な関係が 


\section{存在する。}

溶融層が $\beta$ 相となった後, 雰囲気ガスにより急速に冷 却される．これにより， $\beta$ 相は主として $\alpha$ ママルテンサ イト相へ変態するため，柱状組織内には針状の組織が認 められる.すなわち, SLM 材は造形中に短時間熱処理 ${ }^{20)}$ を施された状態と同じになる，その結果，展伸材の引張 強度が $1030 \mathrm{MPa}$ 程度であるのに対して，SLM 材の引張 強度は $1270 \mathrm{MPa}$ 程度と顕著に高い值となる。

図 14 には, 展伸材と 3 種類の SLM 材の S-N 曲線を示 す.これらのSLM 材では, 積層方向に垂直な面と試験片 （丸棒）軸方向のなす角度が，それぞれ $0^{\circ} ， 45^{\circ}$ および
2D- スライスデータ
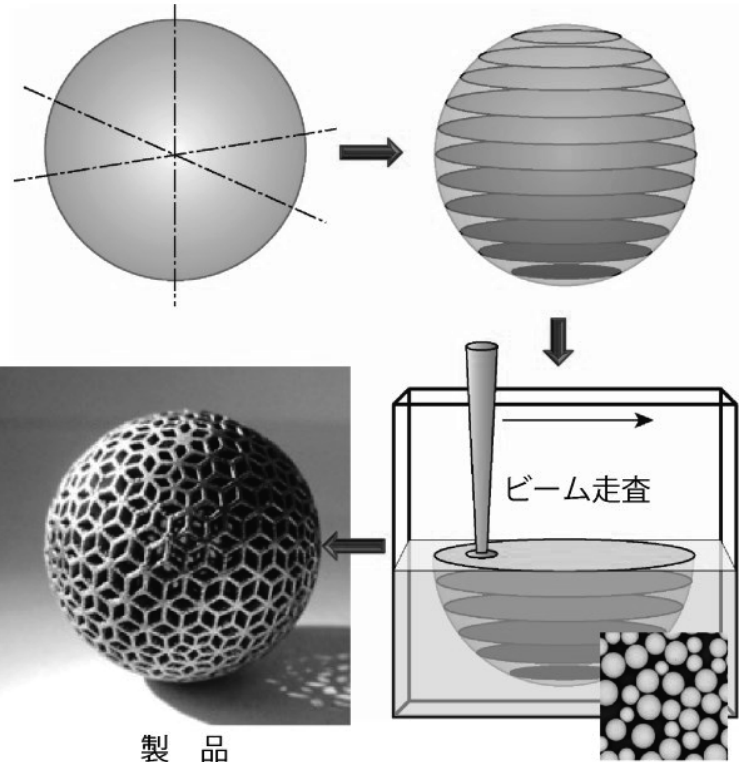

$90^{\circ}$ であった. 図 15 には，展伸材と各 SLM 材の疲労破 面をまとめて示す. なお, 上記の SLM 材では, 疲労試験 片の試験部は鏡面に仕上げられた。

SLM 材における高い引張強度は, 疲労強度の改善を予 想させる。しかしながら，Ti-6Al-4V 合金積層造形材の疲 労強度が展伸材よりも顕著に低い水準に留まることは, 以前から報告されている ${ }^{11), 21)}$ 。実際, 図 14 においても, SLM 材の疲労強度は試験片の積層方向と関係なく，展伸 材よりも大幅に低くなっている，近年における技術発展 により疲労強度は上昇しているが，それでも多方面への 工学的応用を展開する上で，この点は考慮するべき課題

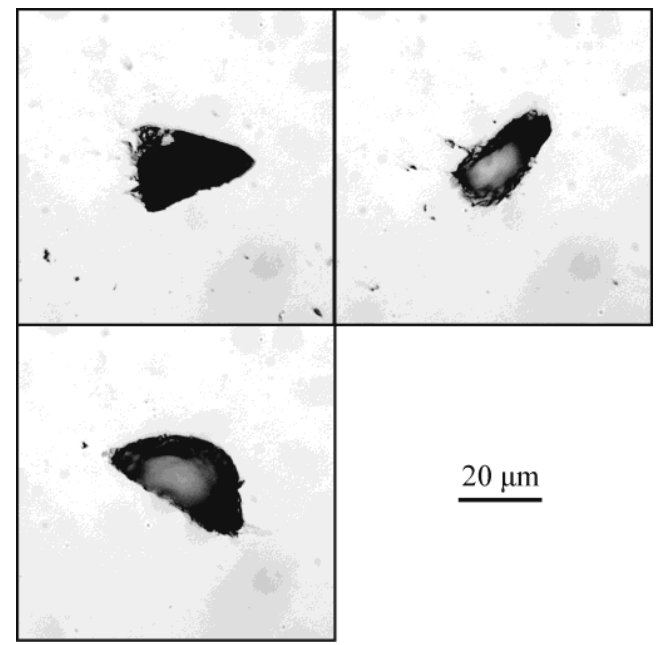

図 12 SLM 材に内包される積層欠陥の例

図 11 積層造形法の説明図

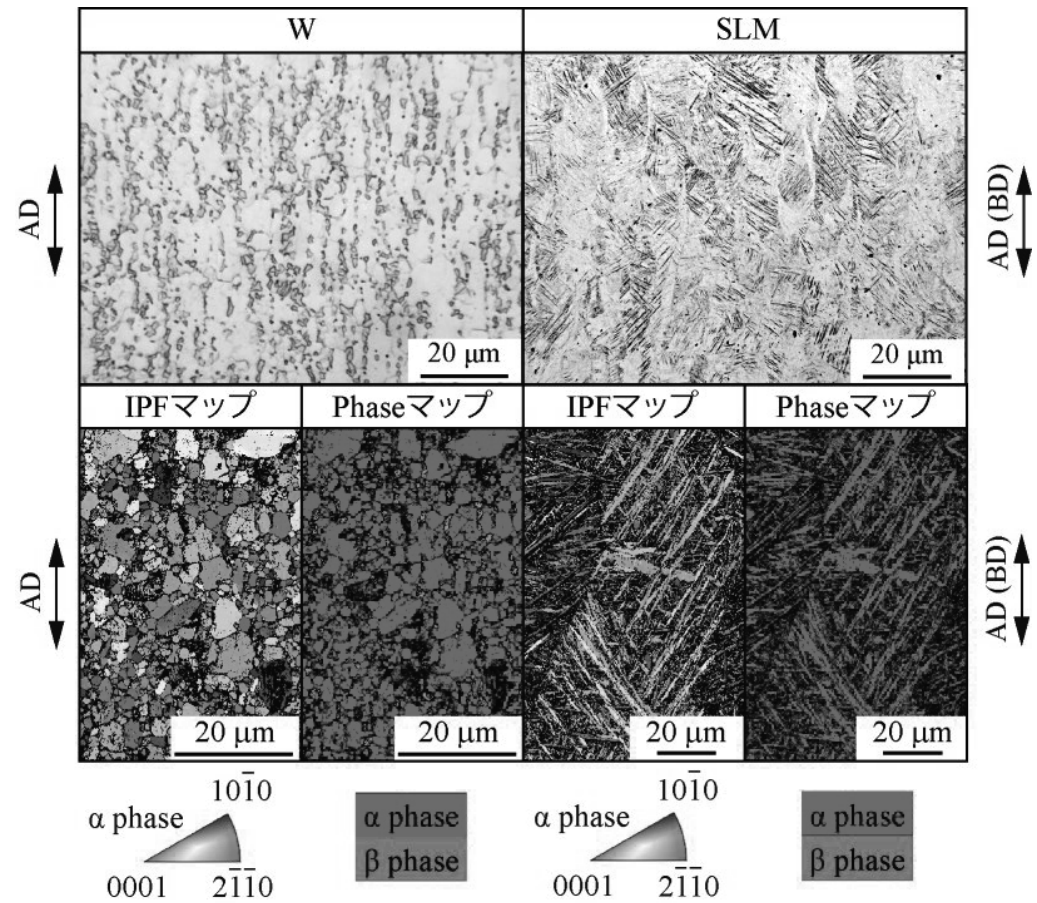

図 13 Ti-6Al-4V 合金展伸材と SLM 材の微視組織 19) 


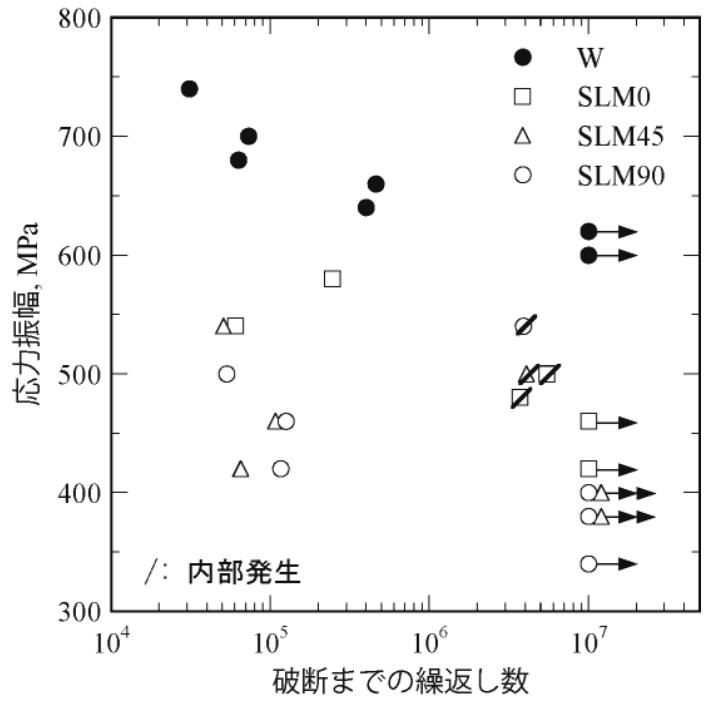

図 14 Ti-6Al-4V 合金展伸材および SLM 材の S-N 曲線（曲げ疲労 試験, 応力比 $R=-1$ ） ${ }^{19)}$

となっている.

図15 から明らかなように，展伸材では表面から発生し たき裂が内部へ向かって放射状に進展寸る. その一方で, SLM 材の疲労き裂は，ほぼ例外なく表面あるいはその近 傍の造形欠陥から発生した後, 内部一進展する。このよ うな形態は，EBM 法により作製した Ti-6Al-4V 合金にお いても同様である ${ }^{22)}$.

チタンおよびその合金において，疲労き裂は停留しな いため, 疲労強度はき裂の発生限界により支配される ${ }^{23)}$. したがって，SLM 材の疲労強度は造形欠陥からのき裂発 生限界の応力水準であると言える，以上より，Ti-6Al- $4 \mathrm{~V}$ 合金積層造形材の疲労強度が低い原因の一つは，造形欠 陥という応力集中部の形成にあると考えられる。

それ以外にも, Ti-6Al-4V 合金積層造形材の疲労強度が 低い原因として, 残留応力が考えられる。一般に, 積層 造形時には，材料内部に高い残留応力が発生すると言わ れている. SLM 材では, 表面に圧縮残留応力が発生する が，深部の残留応力については未だ報告がなされていな い，それゆえ，今後，各種積層造形材の疲労強度に係る 詳細検討のため，材料内部に至る残留応力の測定とその 影響に係る検討が必要となっている.

$$
4 \text { 総括 }
$$

本稿では, FSWにより接合したアルミ合金およびその 異種接合材について，それらの性状および疲労特性につ いて概説した。また，SLM法により作製したチタン合金 積層造形材の性状および疲労特性について説明を行っ た. FSWについては, 疲労特性を含め, 現在までに蓄積 された知見に基づいて工学的応用や技術開発が可能で あると考えられる，その一方で，チタン合金積層造材に ついては, 疲労特性に係る研究結果の蓄積, 技術改良お よび用途開発が今後も引き続き必要となっている.

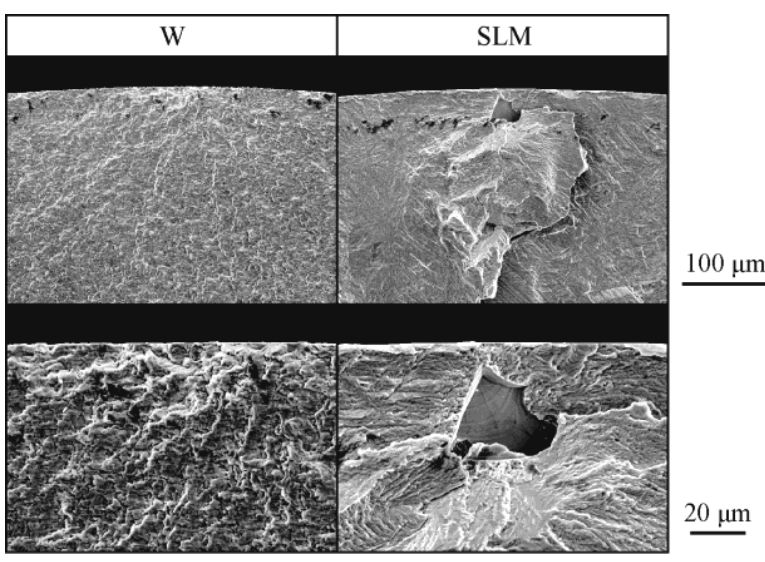

図 15 Ti-6Al-4V 合金展伸材および SLM 材の疲労破面 ${ }^{19)}$

\section{参 考 文 献}

1) Edited by the Japan Welding Society, "Friction stir welding", (2006) Sanpo Press.

2) H. Tokisue, T. Shinoda and M. Kumagai, "Basis and application of friction stir welding", (2005) Nikkan Kogyo Shinbun.

3) G. Lutjering and J.C. Williams, "Titanium", Section 3.6 .2 (2003) Springer.

4) M. Muzvidziwa, M. Okazaki, K. Suzuki and S. Hirano, "Role of Microstructure on the Fatigue Crack Propagation Behavior of a Friction Stir Welded Ti-6Al-4V", Materials Science and Engineering A, Vol.652, pp.59-68 (2016).

5) C. M. Chen and R. Kovacevic, "Joining Al 6061 to AISI 1018 steel by combined effects of fusion and solid state welding", International Journal of Machine Tools \& Manufacture, Vol.44, pp.1205-1214 (2004).

6) M. Fukumoto, M. Tsubaki, Y. Shimoda and T. Yasui, "Welding between $\mathrm{ADC1} 12$ and SS400 by Means of Driction Stirring, Journal of the Japan Welding Society, Vol.22, No.2, pp.309-314 (2004).

7) N. Guo and M.C. Leu, "Additive manufacturing: technology, applications and reseach needs", Frontiers Mechanical Engineering, Vol.8, No.3, pp.215-243 (2013).

8) H. Hideki, T. Nakano, A. Matsuoka and Y. Nakashima, "The development of artificial joints-from the history to future prospects", (2013) Nihon Igakukan.

9) L. E. Svensson, L. Karlsson, H. Larsson, B. Karlsson, M. Fazzini and J. Karlsson, "Microstructure and mechanical properties of friction stir welded alloys with special reference to AA 5083 and AA 6082", Science and Technology of Welding and Joining, Vol.5, No.5, pp.285-296 (2000).

10) M. Simonelli, Y.Y. Tse and C. Tuck, "Effect of build orientation on the mechanical properties and fracture mode of SLM Ti-6Al-4V", Materials Science and Engineering A, Vol.616, pp.1-11 (2014).

11) Q. Liu, J. Elambasseril, S. Sun, M. Leary, M. Milan and P. K. Sharp, "The effect of manufacturing defects on the fatigue behavior of Ti- $6 \mathrm{Al}-4 \mathrm{~V}$ specimens fabricated using selective laser 
melting", Advanced Materials Research, Vol.891-892, pp.1519-1524 (2014).

12) W.M. Thomas, E.D. Nicholas, J.C. Needham, M.G. Murch, P. Templesmith and C.J. Dawes, Friction Stir Butt Welding, International Patent Application PCT/GB92/02203 and GB Patent App 9125978.8, December 1991, US Patent No.5, 460, 317, October 1995.

13) J.Q. Su, T.W. Nelson, R. Mishra and M. Mahoney, "Microstructural investigation of friction stir welded 7075-T651 aluminum", Acta Materialia, Vol.51, pp713-729 (2003).

14) Y.S. Sato, H. Kokawa, M. Enomoto and S. Jogan, "Microstructural evolution of 6063 aluminum during friction-stir welding", Metallurgical and Materials Transactions A, Vol.30A, pp.2429-2437 (1999).

15) T. Morita and M. Yamanaka, "Microstructural evolution and mechanical properties of friction-stir-welded $\mathrm{Al}-\mathrm{Mg}-\mathrm{Si}$ joint", Materials Science and Engineering A, Vol.595, pp.196-204 (2014).

16) M.J. Rathod and M. Kutsuna, "Joining of aluminum alloy 5052 and low-carbon steel by laser roll welding", Welding Journal, Vol. 83, No. 1, pp.16S-26S (2004)

17) M. Yamanaka and T. Morita, "Characteristics of joint of friction-stir-welded aluminum alloy to cold-rolled steel", Transactions of the JSME, Vol.77, No.781, pp.1500-1508 (2011).

18) T. Morita, A. Sakamoto, S. Mabuchi and T. Iizuka, " Strength and formability of friction stir welded aluminum alloy with cold rolled steel", Journal of the Society of Materials Science, Japan, Vol.58, No.4, pp.317-322 (2009).

19) Y. Adachi, T. Morita, C. Tsuda, H. Sakai and N. Higuchi, " Fundamental characteristics of Ti-6Al-4V alloy made by SLM", Proceedings of the 65th JSMS Annual Meetings, No.312 (2016).

20) T. Morita, S. Tanaka and S. Ninomiya, "Improvement in fatigue strength of notched Ti-6Al-4V alloy by short-time heat treatment", Materials Science and Engineering A, Vol.669, pp.127-133 (2016).

21) P. Edwards and M. Ramulu, "Fatigue performance evaluation of selective laser melted Ti-6Al-4V", Materials Science and Engineering A, Vol.598, pp.327-337 (2014).

22) H.K. Rafi, N.V. Karthik, H. Gong, T. L. Starr and B. Stucker, "Microstructures and mechanical properties of Ti6Al4V parts fabricated by selective laser melting and electron beam melting", Journal of Materials Engineering and Performance, Vol. 22, No.12, pp.3872-3883 (2013).

23) T. Takao and H. Nisitani, "Notch sensitivity and behavior of small fatigue cracks of commercial pure titanium, Proceedings of the 2nd Conference of Fatigue, Fatigue Thresholds II, pp.827-834 (1984). 